\title{
PEMETAAN KELAYAKAN LAHAN UNTUK PENGEMBANGAN USAHA BUDI DAYA LAUT DI TELUK SALEH, NUSA TENGGARA BARAT
}

\author{
I Nyoman Radiarta, Adang Saputra, dan Bambang Priono
}

\begin{abstract}
ABSTRAK
Tujuan dari penelitian ini adalah melakukan inventarisasi kelayakan lahan budi daya laut yang disajikan dalam bentuk peta tematik (data spasial). Penelitian telah dilaksanakan di Teluk Saleh, Kabupaten Dompu pada bulan Juli dan Oktober 2003. Penentuan stasiun pengamatan dilakukan secara acak dengan teknik sistematik. Data citra satelit (Landsat ETM+) dan data lapangan (kualitas air: fisik, kimia, dan logam berat) dianalisis dengan metode PATTERN menggunakan Sistem Informasi Geografis (SIG). Hasil survai menunjukkan bahwa kondisi kualitas perairan (fisik, kimia, dan logam berat) masih dalam kisaran yang baik. Faktor eksternal berupa dukungan sarana prasarana cukup memadai demikian pula keterlibatan pemerintah daerah setempat (Dinas Kelautan dan Perikanan) dalam pengembangannya. Total luasan daerah penelitian di Teluk Saleh adalah 8.012 ha. Berdasarkan analisis SIG diperoleh luasan area yang sangat layak untuk budi daya ikan dalam KJA sebesar 267 ha, budi daya rumput laut 542 ha, dan budi daya mutiara 163 ha.
\end{abstract}

\begin{abstract}
Areas suitability mapping for mariculture development in Saleh Bay, West Nusa Tenggara. By: I Nyoman Radiarta, Adang Saputra, and Bambang Priono

The aim of this research is to identify suitability area for mariculture activities which is presented on thematic map (spatial data). The research has been carried out at Saleh Bay, Dompu Regency in July and October 2003. Simple systematic random sampling was used to allocate sampling points. Remote sensing (Landsat ETM+) data and field data (water quality) were analyzed using PATTERN method and Geographic Information System (GIS). Based on the survey, range of the water quality value generally is still good for mariculture activities. As well the external factors such as infrastructures and support from local government (Dinas Keluatan dan Perikanan)are available for supporting mariculture activities in the bay. Total research area at Saleh Bay is 8,012 ha. Based on GIS analysis, the most suitable area for floating net cage, seaweed culture and pearl culture were found 267 ha, 542 ha, and 163 ha respectively.
\end{abstract}

KEYWORDS: $\quad$ site suitability, mariculture, GIS, remote sensing, Saleh Bay

\section{PENDAHULUAN}

Pembangunan budi daya perikanan ke depan harus mampu mendayagunakan potensi yang ada, sehingga dapat mendorong kegiatan produksi berbasis ekonomi rakyat, meningkatkan perolehan devisa negara serta mempercepat pembangunan ekonomi masyarakat pembudi daya ikan di Indonesia secara keseluruhan. Pada saat yang sama, kegiatan budi daya perikanan harus tetap memperhatikan kelestarian sumber daya dan lingkungan dalam rangka mewujudkan kawasan budi daya yang berkelanjutan, berdaya saing, dan berkeadilan.

Indonesia mempunyai potensi budi daya laut yang cukup besar. Berdasarkan hitungan sekitar $5 \mathrm{~km}$ dari garis pantai ke arah laut, potensi lahan kegiatan budi daya laut diperkirakan sekitar 24,53 juta ha (Sukadi, 2002). Luasan potensi kegiatan budi daya laut tersebut terbentang dari ujung bagian barat Indonesia sampai ke ujung wilayah timur Indonesia. Komoditaskomoditas yang dapat dibudidayakan pada areal tersebut antara lain ikan kakap, kerapu, tiram mutiara, rumput laut, abalon, dan teripang. Dari luasan tersebut Pulau Sumbawa (Kabupaten Dompu, Sumbawa, dan Bima) mempunyai potensi sebesar 34.185 ha dengan komoditas budi daya: ikan kerapu, kakap putih, teripang, tiram mutiara, kerang darah, dan rumput laut (Anonim, 2001).

Dalam rangka pembangunan kelautan secara berkelanjutan yang dilakukan oleh setiap pemerintah daerah (kabupaten/kota dan provinsi) sesuai dengan kewenangan pengelolaannya (pasal 3, UU No. 22/ 1999) terdapat lima tahapan yang harus dilaksanakan. Kegiatan inventarisasi dan pemetaan potensi sumber daya merupakan tahapan pertama yang harus dilaksanakan disusul dengan kegiatan penentuan tata

Peneliti pada Pusat Riset Perikanan Budidaya, Jakarta 
ruang, rencana investasi dan pembangunan atas dasar peta tata ruang yang dihasilkan, menyusun kebijakan pengelolaan sumber daya alam dan lingkungan serta kebijakan dan program untuk menciptakan sistem usaha yang kondusif (Dahuri, 2003).

Kabupaten Dompu merupakan salah satu kabupaten yang ada di Provinsi Nusa Tenggara Barat, secara geografis terletak di antara $117^{\circ} 42^{\prime}-{ }^{\prime} 118^{\circ} 30^{\prime}$ Bujur Timur dan $8^{\circ} 06^{\prime}-9^{\circ} 05^{\prime}$ Lintang Selatan, dengan luas wilayah $2.325 \mathrm{~km}^{2}$. Secara administratif kabupaten ini terbagi atas 8 wilayah kecamatan yaitu: Kecamatan Dompu, Woja, Manggelewa, Kempo, Huu, Pajo, Kilo, dan Pekat. Kabupaten ini mempunyai sumber daya pesisir yang cukup potensial yang merupakan aset bagi pembangunan kabupaten tersebut, salah satu di antaranya adalah sektor perikanan. Potensi perikanan Kabupaten Dompu memiliki keunggulan komparatif dan kompetitif yang cukup besar. Sumber daya perikanan Kabupaten Dompu sangat luas termasuk perikanan tangkap dan perikanan budi daya (air tawar, payau, dan laut). Namun jika diukur dari pendapatan asli daerah sektor perikanan dan kelautan relatif masih kecil disebabkan potensi sumber daya alam, sarana, dan prasarana serta kualitas sumber daya manusia yang ada belum dimanfaatkan secara maksimal. Salah satu potensi sumber daya alam yang belum banyak dimanfaatkan adalah sumber daya pesisir dan laut yang luas. Luas perairan pantai mencapai $2.775 \mathrm{~km}^{2}$, perairan lepas pantai $1.734 \mathrm{~km}^{2}$, dan ZEE 26. $723 \mathrm{~km}^{2}$ (Syaiful et al., 2001).

Teknologi inderaja saat ini terus dikembangkan oleh negara maju untuk dapat meningkatkan kemampuannya dalam memperoleh informasi yang akurat mengenai sumber daya alam dan lingkungan. Data inderaja yang diintegrasikan dengan Sistem 1 iformasi Geografis (SIG) akan membentuk data base yang dapat menunjang kebutuhan pengelolaan wilayah pesisir dan lautan, khususnya untuk penyusunan tata ruang wilayah pesisir. Kebutuhan informasi keruangan dalam proses perencanaan tata ruang dapat diakomodasi oleh citra inderaja (Landsat, SPOT, Ikonos), khususnya dalam pembuatan peta administrasi dan peta penggunaan lahan.

Ketersediaan data dan informasi lahan pengembangan budi daya laut yang belum diinventarisasikan secara lengkap (Syaiful et al., 2001; Hakim et al., 2000) merupakan satu kendala utama dalam pembangunan budi daya laut di Kabupaten Dompu, sehingga berimplikasi tehadap tumpang tindihnya pemanfaatan ruang perairan baik antar sektor maupun lintas sektoral. Sebagai contoh terganggunya lahan budi daya rumput laut oleh aktivitas transportasi kapal/perahu dan bagan serta sebaliknya terganggunya jalur pelayaran nelayan akibat semrawutnya budi daya rumput laut. Sehubungan dengan hal tersebut, penelitian ini bertujuan untuk melakukan inventarisasi kelayakan lahan budi daya laut yang disajikan dalam bentuk peta tematik. Hasil dari penelitian ini diharapkan menjadi masukan bagi pemerintah daerah untuk mengalokasikan pengembangan budi daya laut serta dalam rangka menyusun rencana tata ruang wilayah.

\section{BAHAN DAN METODE}

Penelitian ini telah dilakukan pada bulan Juli dan Oktober 2003, dengan mengambil lokasi di Teluk Saleh, Kabupaten Dompu. Secara administrasi Teluk Saleh merupakan perairan yang dikelola oleh dua kabupaten yaitu Kabupaten Sumbawa dan Dompu, membujur dari $117^{\circ} 24^{\prime}-$-118$^{\circ} 18^{\prime}$ Bujur Timur dan 08 $09^{\prime}$ $-08^{\circ} 44^{\prime}$ Lintang Selatan. Dalam rangka menunjang pengembangan tata ruang wilayah pesisir dan laut Pemda Provinsi NTB menetapkan Teluk Saleh sebagai zona pengembangan optimis (Anonim, 2001) yaitu pengembangan tata ruang pesisir dan laut yang mempunyai nilai ekonomis tinggi di masa datang dan kelestarian lingkungan yang ada tetap terjaga dengan terobosan-terobosan atau inovasi baru terutama untuk pengembangan budi daya rumput laut dan mutiara.

Daerah penelitian terletak di kawasan Teluk Saleh yang masuk Kabupaten Dompu, membujur dari 118 $10^{\prime}$ -118 $17^{\prime}$ Bujur Timur dan $08^{\circ} 32^{\prime}--08^{\circ} 40^{\prime}$ Lintang Selatan. Total luas daerah penelitian di Teluk Saleh adalah 8.012 ha, yang termasuk dalam dua kecamatan yaitu Kecamatan Manggelewa dan Kempo (Gambar 1). Perairan ini sangat berpotensi bagi pengembangan budi daya laut, karena perairannya terlindung dan relatif tenang. Selain itu juga didukung oleh pemerintah daerah yang dalam perencanaan tata ruang wilayah menetapkan kawasan pesisir Kecamatan Kempo dan Manggelewa masuk dalam zona perikanan budi daya laut yaitu diperuntukkan bagi perikanan budi daya mutiara dan rumput laut serta sebagian kecil zona budi daya air payau yang terletak di Desa Kwanko, Kecamatan Manggelewa (Anonim, 2001).

Metode yang dipakai dalam penelitian ini adalah metode survai yang dirancang berdasarkan Sistem Informasi Geografis (SIG). Penentuan titik pengamatan dirancang dengan simple random dan systematic random sampling (Clark \& Hosking, 1986; Morain, 1999) dengan jarak $1,5 \mathrm{~km}$ (arah vertikal dan horizontal) antara titik pengamatan. Posisi sampling telah ditentukan berdasarkan informasi survai pendahuluan dan sebelum survai ke lapangan. Global Positioning System (GPS) dalam systematic random sampling di lapangan hanya berfungsi sebagai tracking. Sebanyak 66 titik pengamatan kualitas perairan telah dikumpulkan dan 15 titik pengamatan diambil contoh air dan tanah untuk dianalisis di 


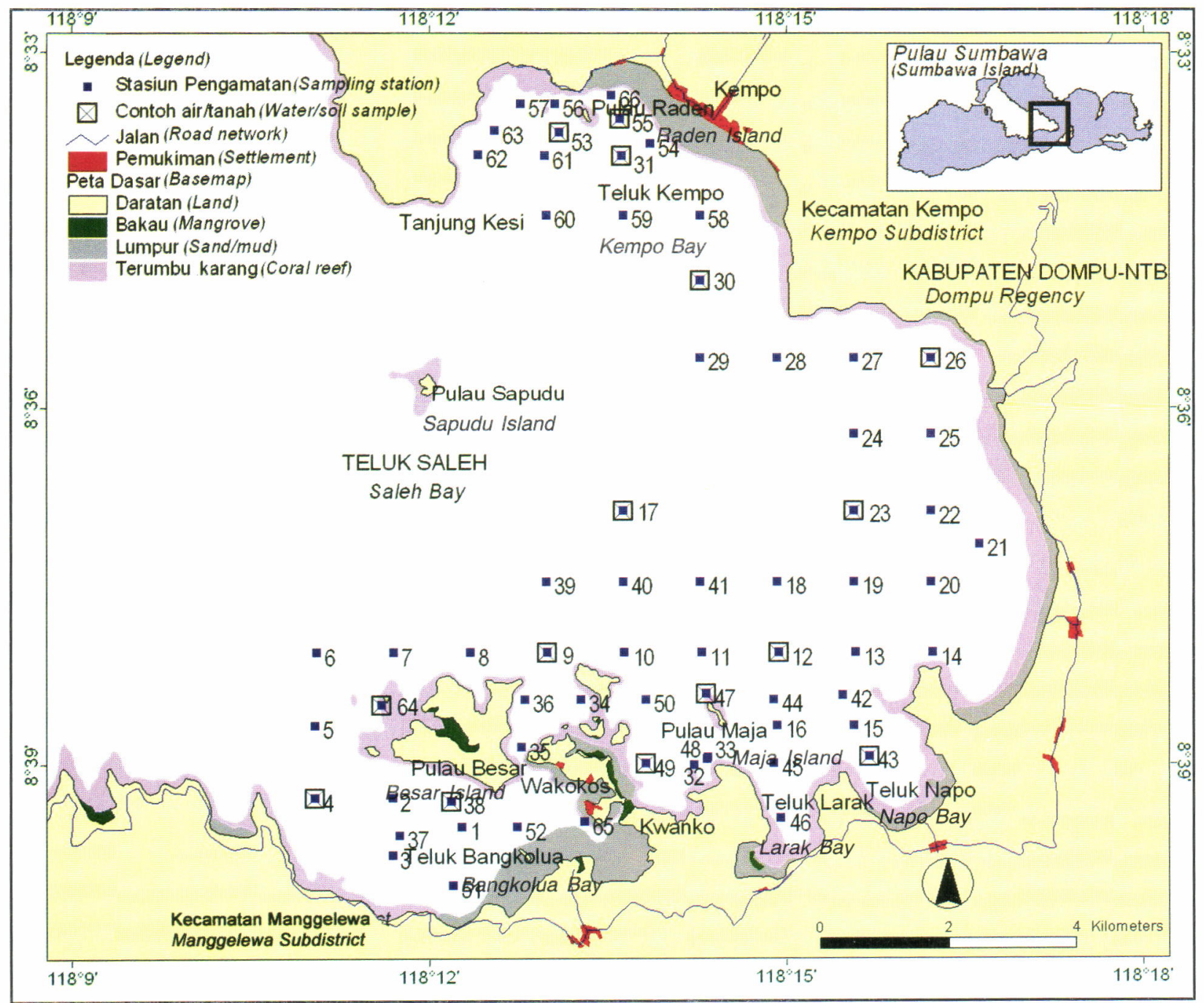

Gambar 1. Tampilan umum lokasi penelitian di Teluk Saleh dan distribusi lokasi pengamatan kualitas perairan Figure 1. General features of Saleh Bay and distribution of water quality sampling points

laboratorium. Sebaran titik sampling dan ekosistem di lokasi penelitian dapat dilihat pada Gambar 1. Selain data kualitas perairan, dikumpulkan juga data sosial ekonomi. Pengambilan data sosial ekonomi berdasarkan kuesioner yang dilakukan melalui wawancara dengan beberapa responden secara acak di kedua kecamatan yang masuk dalam lokasi penelitian.

Data yang dikumpulkan dalam penelitian ini terdiri atas data primer dan data sekunder. Data primer yang dikumpulkan adalah data kualitas perairan yang meliputi: parameter fisik (luasan, kedalaman, suhu air, kecerahan, tinggi gelombang, kecepatan arus), kimia (salinitas, pH, DO, fosfat, nitrat, nitrit, amonia), logam berat (kadmium $(\mathrm{Cd})$, seng $(\mathrm{Zn})$, timbal $(\mathrm{Pb})$, tembaga (Cu)), dan kualitas sedimen (tekstur) serta data sosial ekonomi. Data sekunder berupa peta dasar lokasi penelitian. Peta dasar ini bersumber dari hasil digitasi citra satelit Landsat ETM+ (aquisisi 20 Juli 2000) path114/row 066 keluaran LAPAN dan Bappedal, peta rupa bumi skala 1:25.000 (sheet: 1907-332, 1907334, 1907-341, dan 1907-343) keluaran Bakosurtanal dan peta batimetri keluaran Dinas Hidro Oseanografi. Tema utama dari peta dasar yang diambil meliputi: garis pantai, mangrove, terumbu karang, lumpur (sedimentasi), sungai, jalan, sebaran penduduk, dan kedalaman perairan.

Evaluasi kelayakan lahan dilakukan dengan metode PATTERN (Planning Assisstance Through Technical Evaluation of Relevant Numbers) yang diterapkan untuk memecahkan masalah melalui pengambilan skor pada setiap kategori di setiap faktor dari informasi geografi (Bakosurtanal, 1995 dalam Saefuddin et al., 1996). PATTERN adalah metode untuk menghitung tingkat relatif dari kontribusi untuk setiap faktor lahan geografis untuk sampai pada tujuan akhir. Faktor-faktor lahan geografis diberikan pada bentuk peta-peta tematik, dan tujuan akhir 
adalah peta kelayakan lahan untuk budi daya laut. Pada metode ini setiap kategori di setiap faktor ditentukan dengan angka skor, dan total skor dihitung sebagai jumlah pembobotan dari setiap skor kategori (Treece, 2000). Bobot ditentukan melalui ketergantungan dari setiap faktor yang dikaitkan dengan tujuan.

Data kualitas perairan yang dikumpulkan dari lapangan berasal dari titik pengamatan yang penyebarannya mewakili lokasi penelitian. Untuk menganalisis secara spasial, titik-titik tersebut terlebih dahulu harus dilakukan interpolasi, yang merupakan suatu metode dalam pengolahan data titik menjadi area (polygon). Cara interpolasi titik menjadi area menggunakan metode Nearest Neighbour (Burrough \& McDonnell, 1998; Morain, 1999). Dari hasil interpolasi masing-masing parameter kualitas perairan yang diperoleh kemudian disusun dalam bentuk peta tematik. Luasan perairan yang layak bagi pengembangan budi daya laut dihasilkan setelah seluruh data parameter utama pembobotan dalam bentuk peta tematik di-overlay-kan (tumpang susunkan). Diagram alur analisis spasial penentuan lokasi pengembangan budi daya laut dapat dilihat pada Gambar 2

Kriteria yang digunakan dalam penyusunan matrik kesesuaian dan pembobotan untuk penentuan kelayakan lahan budi daya laut mengacu pada kriteria yang telah disusun oleh beberapa peneliti di antaranya budi daya ikan dalam keramba jaring apung oleh Ahmad et al. (1995), Imanto et al. (1995), Ismail et al. (1998), Mayunar et al. (1995), dan Beveridge (1996); budi daya rumput laut oleh Mubarak et al. (1990); dan budi daya mutiara oleh CMFRI (1991) dan Winanto (2004). Tabel 1 menyajikan matrik kesesuaian dan pembobotan data untuk penentuan kelayakan lahan budi daya laut.

Analisis data dilakukan dengan cara overlay dari beberapa peta tematik yang diperlukan. Penilaian secara kuantitatif terhadap tingkat kelayakan lahan dilakukan melalui skoring dengan faktor pembobot. Parameter yang mempunyai pengaruh dominan dan relatif tidak dapat diubah memiliki faktor pembobot yang paling besar, sebaliknya parameter yang kurang dominan memiliki faktor pembobot yang lebih kecil. Lahan yang masuk kategori sangat layak (S1) memiliki nilai total 30, kategori cukup layak (S2) memiliki nilai total 20, dan kategori tidak layak (N) memiliki nilai total 10. Analisis secara kuantitatif menggunakan pendekatan: $Y=\sum a i . X n$

$$
\text { di mana: } \begin{aligned}
Y & =\text { nilai akhir } \\
\text { ai } & =\text { faktor pembobot } \\
X_{n} & =\text { nilai tingkat kesesuaian lahan }
\end{aligned}
$$

Gambar 2. Diagram alur penentuan lokasi pengembangan budi daya laut Figure 2. Flow chart of site selection method for mariculture development 
Tabel 1. Matrik kesesuaian dan pembobotan data kualitas air pemilihan lokasi budi daya laut Table 1. Suitability matrik and weghting value of water quality data for mariculture site selection

Keramba jaring apung (floating net cage)

\begin{tabular}{|c|c|c|c|c|c|}
\hline \multirow{2}{*}{$\begin{array}{l}\text { Parameter } \\
\text { Parameters }\end{array}$} & \multirow{2}{*}{$\begin{array}{c}\text { Satuan } \\
\text { Unit }\end{array}$} & \multirow{2}{*}{$\begin{array}{c}\text { Bobot } \\
\text { Weight }(\%)\end{array}$} & \multicolumn{3}{|c|}{ Nilai (Value) } \\
\hline & & & 30 & 20 & 10 \\
\hline Morfologi & & 20 & Terlindung & Cukup terlindung & Terbuka \\
\hline Morphology & & & Close & Moderately close & Open \\
\hline Kedalaman (Water depth) & $\mathrm{m}$ & 15 & $8--15$ & $16-25$ & $<8 \&>25$ \\
\hline Arus (Water current) & $\mathrm{cm} / \mathrm{dt}$ & 10 & $5--15$ & $16-30$ & $<5 \&>30$ \\
\hline Substrat dasar & & 10 & Pasir dan pecahan karang & Pasir berlumpur & Lumpur \\
\hline Sediment & & & Sand and rubble & Sandy clay & Clay \\
\hline Kecerahan (Transparency) & $\mathrm{m}$ & 10 & $>3$ & $1-3$ & $<1$ \\
\hline Salinitas (Salinity) & ppt & 10 & $30--35$ & $20--29$ & $<20 \&>35$ \\
\hline Pencemar (Pollutan) & & 10 & Tidak ada (Low) & Sedang (Moderat) & ) Tinggi (High) \\
\hline Keamanan & & 5 & Aman & Agak aman & Tidak aman \\
\hline Security & & & Good & Fair & Poor \\
\hline Keterjangkauan & & 5 & Mudah & Agak sulit & Sulit \\
\hline Accessibility & & & Good & Fair & Poor \\
\hline Tenaga kerja & & 5 & Mudah & Agak sulit & Sulit \\
\hline Availability of labour & & & Good & Fair & Poor \\
\hline
\end{tabular}

Budi daya rumput laut (seaweed culture)

\begin{tabular}{|c|c|c|c|c|c|}
\hline \multirow{2}{*}{$\begin{array}{l}\text { Parameter } \\
\text { Parameters }\end{array}$} & \multirow{2}{*}{$\begin{array}{c}\text { Satuan } \\
\text { Unit }\end{array}$} & \multirow{2}{*}{$\begin{array}{c}\text { Bobot } \\
\text { Weight (\%) }\end{array}$} & \multicolumn{3}{|c|}{ Nilai (Value) } \\
\hline & & & 30 & 20 & 10 \\
\hline Morfologi & & 15 & Terlindung & Cukup terlindung & Terbuka \\
\hline Morphology & & & Close & Moderately close & Open \\
\hline Kedalaman (Water depth) & m & 15 & $1-10$ & $11--15$ & $<1 \&>15$ \\
\hline Arus (Water current) & $\mathrm{cm} / \mathrm{dt}$ & 10 & $20-30$ & $31--40$ & $<20 \&>40$ \\
\hline Substrat dasar & & 10 & Pasir dan pecahan karang & Pasir berlumpur & Lumpur \\
\hline Sediment & & & Sand and rubble & Sandy clay & Clay \\
\hline Kecerahan (Transparency) & $\mathrm{m}$ & 10 & $>3$ & $1-3$ & $<1$ \\
\hline Salinitas (Salinity) & ppt & 10 & $32-34$ & 28--31 & $<28 \&>34$ \\
\hline Hewan herbivore & & 5 & Tidak ada & Sedang & Tinggi \\
\hline Herbivor animal & & & Low & Moderat & High \\
\hline Pencemar & & 10 & Tidak ada & Sedang & Tinggi \\
\hline Pollutan & & & Low & Moderat & High \\
\hline Keamanan & & 5 & Aman & Agak aman & Tidak aman \\
\hline Security & & & Good & Fair & Poor \\
\hline Keterjangkauan & & 5 & Mudah & Agak sulit & Sulit \\
\hline Accessibility & & & Good & Fair & Poor \\
\hline Tenaga kerja & & 5 & Mudah & Agak sulit & Sulit \\
\hline Availability of labour & & & Good & Fair & Poor \\
\hline
\end{tabular}

Untuk mendapatkan selang nilai pada setiap kategori ditentukan dari nilai persentase dari hasil perhitungan di atas. Dengan demikian akan diperoleh kisaran persentase setiap kategori sebagai berikut:
- Kategori sangat layak (S1): $\quad Y=85 \%$

- Kategori layak (S2)

$Y=50 \%-84 \%$

- Kategori tidak layak (N) : $\mathrm{Y}=50 \%$ 
Budi daya tiram mutiara (pearl culture)

\begin{tabular}{|c|c|c|c|c|c|}
\hline \multirow{2}{*}{$\begin{array}{l}\text { Parameter } \\
\text { Parameters }\end{array}$} & \multirow{2}{*}{$\begin{array}{c}\text { Satuan } \\
\text { Unit }\end{array}$} & \multirow{2}{*}{$\begin{array}{c}\text { Bobot } \\
\text { Weight }(\%)\end{array}$} & \multicolumn{3}{|c|}{ Nilai (Value) } \\
\hline & & & 30 & 20 & 10 \\
\hline Morfologi & & 10 & Terlindung & Cukup terlindung & Terbuka \\
\hline Morphology & & & Close & Moderately close & Open \\
\hline Kedalaman (Water depth) & m & 15 & $10-20$ & $21--30$ & $<10 \&>30$ \\
\hline Arus (Water current) & $\mathrm{cm} / \mathrm{dt}$ & 10 & 5--15 & $16--30$ & $<5 \&>30$ \\
\hline Substrat dasar & & 10 & Batu kerikil & Pecahan karang dan pasir & lumpur \\
\hline Sediment & & & Gravelly & Rubble and sand & clay \\
\hline Kecerahan (Transparency) & $\mathrm{m}$ & 10 & $3--5$ & $1-4$ & $<1$ \\
\hline Salinitas (Salinity) & ppt & 10 & 24--38 & $15-24$ & $<15 \&>38$ \\
\hline Kesuburan perairan* & & 10 & Banyak & Sedang & Sedikit \\
\hline Water fertility & & & High & Moderat & Low \\
\hline Pencemar & & 10 & Tidak ada & Sedang & Tinggi \\
\hline Pollutan & & & Low & Moderat & High \\
\hline Keamanan & & 5 & Aman & Agak aman & Tidak aman \\
\hline Security & & & Good & Fair & Poor \\
\hline Keterjangkauan & & 5 & Mudah & Agak sulit & Sulit \\
\hline Accessibility & & & Good & Fair & Poor \\
\hline Tenaga kerja & & 5 & Mudah & Agak sulit & Sulit \\
\hline Availability of labour & & & Good & Fair & Poor \\
\hline
\end{tabular}

* berdasarkan jenis dan kelimpahan plankton (based on total species and abundance of plankton)

\section{HASIL DAN BAHASAN}

\section{Kondisi Umum Perairan}

Teluk Saleh merupakan perairan semi tertutup yang berhubungan langsung dengan Laut Flores. Secara geografis teluk ini terletak pada posisi $117^{\circ}-118^{\circ}$ Bujur Timur dan $8,1^{\circ}-8,8^{\circ}$ Lintang Selatan. Pola arus yang masuk dan keluar baik pada saat pasut kondisi perbani (Neap Tide Condition) dan pasut kondisi purnama (Sping Tide Condition) ke dalam teluk lebih dominan melalui Selat Batahai (sebelah timur Pulau Moyo) dibandingkan dengan Selat Saleh (sebelah barat daya Pulau Moyo). Hal ini disebabkan dasar Selat Batahai lebih dalam dari Selat Saleh. Pertemuan dua arus ini mengakibatkan terbentuknya arus memutar yang terkonsentrasi di bagian utara perairan. Dengan adanya arus memutar di bagian utara teluk, menyebabkan perairan Teluk Saleh bagian utara jauh lebih dinamis dibandingkan dengan bagian selatan/ujung dalam teluk (Supangat et al., 2003).

Kondisi pasang surut di Teluk Saleh berdasarkan pengamatan hasil prediksi yang dilakukan oleh Supangat et al. (2003) diperoleh bahwa tipe pasang surut di perairan Teluk Saleh adalah tipe campuran yang cenderung ke harian ganda ( $m i x e d$ semi diurnal). Prediksi tersebut menunjukkan bahwa pada bulan Oktober 2003 tinggi rata-rata air pasang tertinggi adalah $+74,56 \mathrm{~cm}$ dan air surut terendah $69,12 \mathrm{~cm}$.
Dari hasil analisis citra satelit Landsat ETM+, diperoleh gambaran letak geografis lokasi survai (bagian dalam teluk) pada posisi $118^{\circ} 10^{\prime}-118^{\circ} 17^{\prime}$ Bujur Timur dan $08^{\circ} 32^{\prime}-08^{\circ} 40^{\prime}$ Lintang Selatan. Total luasan daerah survai mencapai 8.012 ha. Di dalam kawasan penelitian terdapat beberapa pulau kecil (Pulau Maja, Pulau Besar, Pulau Wakokos, Pulau Secangkir) yang terdapat di Kecamatan Manggelewa serta dua pulau (Pulau Sapudu dan Pulau Raden) yang terdapat di Kecamatan Kempo. Pulau-pulau ini sangat berguna sebagai penghalang gelombang yang menjadikan perairan ini relatif tenang dan terlindung dari ombak. Beberapa jenis ekosistem dominan yang terdapat di sekitar teluk dapat dipetakan dan dihitung luasannya yang meliputi: hutan bakau 33 ha, terumbu karang 648 ha, dan lumpur/pasir 567 ha. Gambar 3 menampilkan lokasi penelitian dengan data Landsat ETM+. Dari hasil analisis menunjukkan bahwa kombinasi band 543 (Red Green Blue) dari sensor Landsat ETM+ menampakkan secara jelas perbedaan spektral untuk tiap tutupan lahan pada wilayah daratan dan perairan, sehingga akan memudahkan pengklasifikasian secara tepat untuk lahan yang sesuai.

\section{Kondisi Perairan Teluk}

Secara umum kualitas perairan permukaan terutama parameter fisik dan kimia di 66 titik pengamatan di Teluk Saleh masih dalam batas 
toleransi bagi kegiatan budi daya laut. Sampling dilakukan pada pukul 09:30 WITA sampai dengan pukul 16:30 WITA. Perbedaan waktu sampling ini juga sangat berpengaruh pada beberapa parameter kualitas perairan di antaranya suhu air dan kandungan oksigen (DO). Kisaran nilai kualitas perairan yang diperoleh dari hasil pengamatan di lapangan secara ringkas disajikan pada Tabel 2 .

Dari hasil pengukuran parameter fisik dan kimia perairan menunjukkan bahwa perairan di lokasi penelitian masih sangat baik untuk kegiatan budi daya laut. Suhu air dengan kisaran $27,5^{\circ} \mathrm{C}-32,8^{\circ} \mathrm{C}$ masih tergolong dalam kategori baik untuk budi daya laut. Seperti yang dikemukakan oleh Mayunar et al. (1995) bahwa suhu air untuk kegiatan budi daya ikan yaitu $27^{\circ} \mathrm{C}-32^{\circ} \mathrm{C}$, sedangkan untuk budi daya rumput laut kisaran suhu yang baik $20^{\circ} \mathrm{C}-28^{\circ} \mathrm{C}$ (Mubarak et al., 1990). Kecerahan perairan masih dalam kategori yang baik untuk budi daya laut yaitu $3 \mathrm{~m}$. Kecerahan yang nilainya kurang dari $3 \mathrm{~m}$ ditemukan di lokasi yang letaknya dekat dengan perairan yang dasarnya lumpur yaitu pada stasiun 66 dan 65 . Tinggi gelombang dan kecepatan arus berdasarkan hasil pengukuran mempunyai kisaran nilai antara 5-100 cm dan 10$90 \mathrm{~cm} / \mathrm{dt}$, kisaran nilai tersebut masih dalam kategori yang baik untuk kegiatan budi daya.

Kedalaman perairan merupakan parameter fisik utama lainnya yang perlu diperhatikan. Hasil

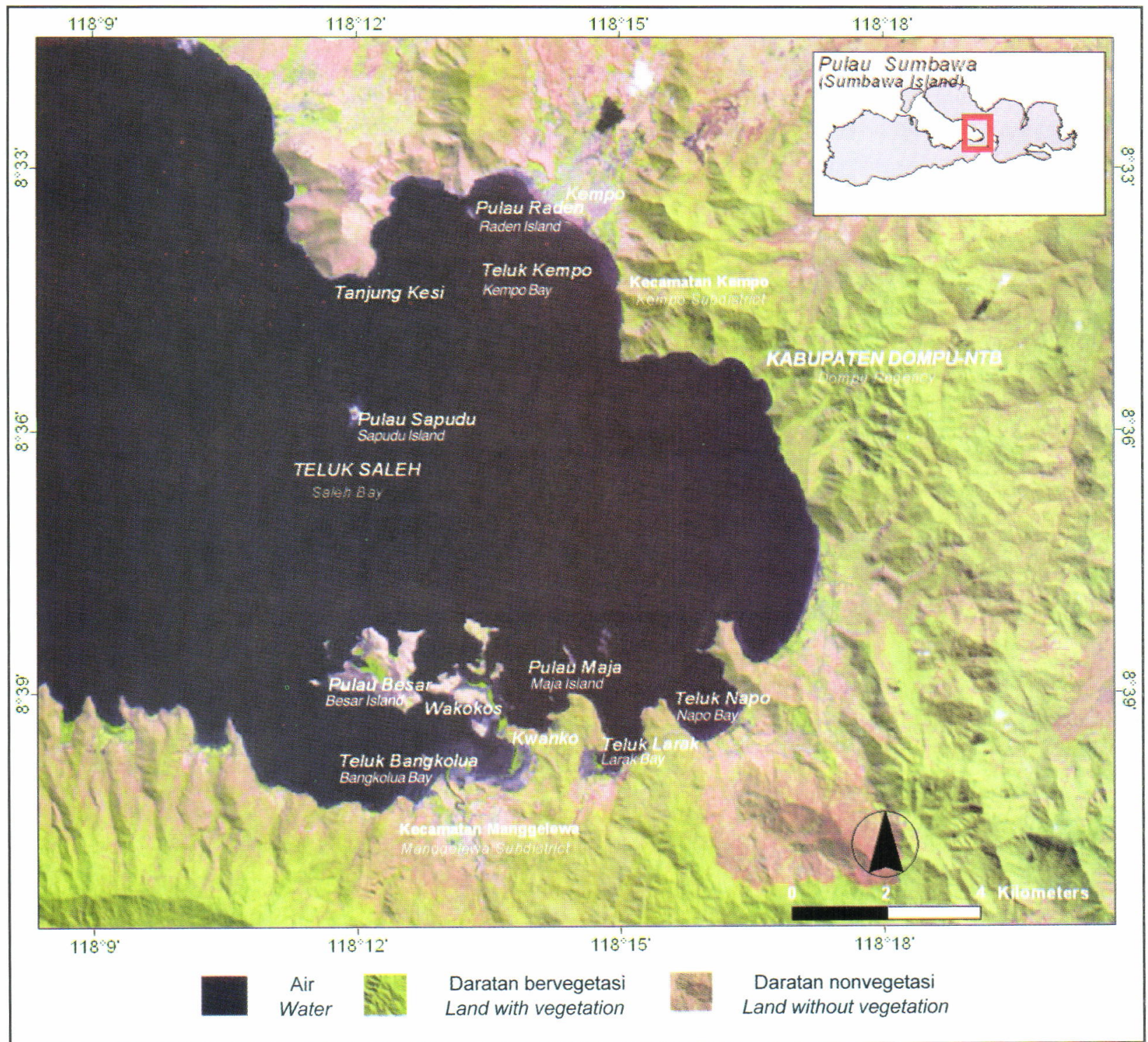

Gambar 3. Gambaran umum lokasi penelitian di Teluk Saleh dengan Landsat ETM+ band 543 (RGB) akuisisi 20 Juli 2000

Figure 3. General feature of research location at Saleh Bay using Landsat ETM+ band 543 (RGB) aquired on July 20, 2000 
penggabungan data kedalaman dari pengukuran lapangan dan data batimetri Dishidros menunjukkan kisaran kedalaman antara 1-41 m. Beveridge (1996) menyaratkan bahwa kedalaman ideal perairan pada saat surut antara keramba jaring apung dengan dasar perairan adalah $4-5 \mathrm{~m}$. Hal ini memberikan ruang terjadinya pertukaran nutrien atau limbah sisa KJA. Sedangkan untuk budi daya mutiara kedalaman yang optimal adalah $10 \mathrm{~m}$. Hal ini dimungkinkan untuk menghindari adanya sedimentasi.

Salinitas perairan berkisar antara 22-32 ppt tergolong masih baik untuk kegiatan budi daya laut. Untuk kegiatan budi daya ikan dalari KJA, kisaran salinitas yang baik tergantung pada jenis ikan yang akan dibudidayakan. Sebagai contoh, untuk jenis ikan kerapu salinitas yang diinginkan berkisar antara 2035 ppt (Sutarmat et al., 2003; APEC/SEAFDEC, 2001). Kandungan oksigen (DO) dalam perairan sangat penting bagi sintasan hewan tersebut. Untuk kegiatan budi daya kandungan DO yang diinginkan adalah $>5 \mathrm{mg} / \mathrm{L}(\mathrm{KLH}, 2004)$. Dari hasil pengukuran menunjukkan bahwa DO berkisar antara 4,7-9,2 mg/ $\mathrm{L}$, hal ini berarti masih dalam kisaran yang baik untuk kegiatan budi daya perikanan.

Parameter lain yang perlu mendapat perhatian adalah kandungan logam berat. Secara alamiah, unsur-unsur logam berat terdapat di mana-mana dalam konsentrasi sangat rendah. Konsentrasi tersebut akan meningkat sejalan dengan bertambahnya aktivitas manusia seperti: perindustrian, pertambangan, dan pertanian serta limbah perkotaan dan buangan lainnya yang banyak mengandung logam berat. Hasil analisis laboratorium untuk parameter kimia (fosfat, nitrat, nitrit, dan amoniak) dan logam berat ( $\mathrm{Cd}, \mathrm{Zn}, \mathrm{Pb}$, dan $\mathrm{Cu}$ ) di 15 titik pengamatan dapat dilihat pada Tabel 3.
Kisaran logam berat di lokasi studi untuk timbal $(\mathrm{Pb})$ berkisar $0,001-0,061 \mathrm{mg} / \mathrm{L}$, kadmium $(\mathrm{Cd})$ $0,0004-0,0016 \mathrm{mg} / \mathrm{L}$, temibaga $(\mathrm{Cu}) 0,003-0,009$ $\mathrm{mg} / \mathrm{L}$, dan seng $(\mathrm{Zn})$ 0,0018-0,0143 $\mathrm{mg} / \mathrm{L}$, masih dalam kisaran aman dan memenuhi syarat untuk kegiatan budi daya biota laut (KLH, 2004). Konsentrasi fosfat, nitrit, dan nitrat masih kecil sedangkan amonia cukup tinggi namun konsentrasi secara keseluruhan masih dalam kisaran yarig baik untuk kegiatan budi daya biota laut.

Selain data kualitas perairan, di beberapa titik pengamatan juga dilakukan pengambilan data tekstur sedimen dasar perairan. Hasil analisis sedimen dasar menunjukkan: persentase pasir berkisar antara $2 \%$ $90 \%$, liat $8 \%-46 \%$, dan debu $2 \%-77 \%$. Hal ini menunjukkan bahwa jenis sedimen substrat dasar didominasi oleh pasir, pasir berlempung, dan lempung berpasir. Data ini sangat erat kaitannya dengan kemungkinan untuk penempatan KJA dan rancangan konstruksi KJA terutama untuk tipe jangkar yang akan dipakai. Selain berpengaruh terhadap kemudahan pemasangan fasilitas budi daya, juga dapat berpengaruh terhadap produktivitas perairan, kekeruhan perairan, dan sedimentasi.

Kesuburan perairan yang dilihat dari kelimpahan plankton merupakan satu faktor yang penting dalam kaitannya dengan budi daya tiram mutiara. Kelimpahan plankton yang cukup merupakan sumber makanan yang baik bagi tiram mutiara yang dibudidayakan, tapi jika kelimpahan plankton sampai melebihi batas (blooming) harus dihindari karena mencirikan terjadinya pencemaran biologi. Hasil pengamatan menunjukkan jumlah jenis plankton berkisar 13-25 jenis dan kelimpahan berkisar antara $25.15-301.800$ ind./L. Jenis yang dominan di antaranya Thalassiosira, Coscinodiscus,

Tabel 2. Kisaran nilai kualitas perairan di Teluk Saleh, Kabupaten Dompu

Table 2. Value range of water quality at Saleh Bay, Dompu Regency

\begin{tabular}{lcc}
\hline \multicolumn{1}{c}{ Parameter (Parameters) } & Satuan (Unit) & Kisaran nilai (Value range) \\
\hline Fisika (Physical): & $\mathrm{o}$ & $27.5-32.8(28.9 \pm 1.2)$ \\
Suhu (Water temperature) & $\mathrm{C}$ & $1.0--9.5(5.1 \pm 1.8)$ \\
Kecerahan (Transparency) & $\mathrm{cm} / \mathrm{dt}$ & $10--90(35.6 \pm 17.5)$ \\
Arus (Water current) & $\mathrm{m}$ & $1-41(13.98 \pm 8.05)^{*}$ \\
Kedalaman (Water depth) & $\mathrm{cm}$ & $5-100(38.7 \pm 26.9)$ \\
Gelombang (High wave) & & $8.50-8.65(8.6 \pm 0.05)$ \\
\hline Kimia (Chemical): & & $22-32(29 \pm 2)$ \\
pH & $\mathrm{ppt}$ & $4.7-9.2(6.05 \pm 0.80)$ \\
Salinitas (Sainity) & $\mathrm{mg} / \mathrm{L}$ & \\
Oksigen terlarut (Dissoived oxygen) & & \\
\hline
\end{tabular}

*)data lapangan dan data batimetri Dishidros, $N=402$ (field data and bathymetri data- Dishidros, $N=402$ ) -(rataan \pm simpangan baku) (average \pm standard deviation) 
Tabel 3. Konsentrasi logam berat di Teluk Saleh, Kabupaten Dompu

Table 3. Heavy metal consentration at Saleh Bay, Dompu Regency

\begin{tabular}{|c|c|c|c|c|c|c|c|c|}
\hline \multirow[b]{2}{*}{ Stasiun (Station) } & \multicolumn{4}{|c|}{ Kimia (Chemical parameters) } & \multicolumn{4}{|c|}{ Logam berat (Heavy metal) (mg/L) } \\
\hline & $\begin{array}{c}\text { Fosfat } \\
\text { Phosphate }\end{array}$ & $\begin{array}{c}\text { Nitrit } \\
\text { Nitrite }\end{array}$ & $\begin{array}{l}\text { Nitrat } \\
\text { Nitrate }\end{array}$ & $\begin{array}{c}\text { Amonia } \\
\text { Ammonia }\end{array}$ & $\mathrm{Pb}$ & Cd & $\mathrm{Cu}$ & $\mathrm{Zn}$ \\
\hline 4 & 0.041 & 0.309 & 0.0150 & - & 0.001 & 0.0016 & 0.0034 & 0.0061 \\
\hline 9 & 0.035 & 0.328 & 0.0086 & - & 0.0269 & 0.0004 & - & 0.0081 \\
\hline 12 & 0.035 & 0.318 & 0.0150 & - & 0.0179 & 0.0012 & 0.0034 & 0.0018 \\
\hline 17 & 0.041 & 0.318 & 0.0110 & & 0.0179 & 0.0012 & - & 0.0029 \\
\hline 23 & 0.041 & 0.299 & 0.0130 & - & 0.0179 & 0.0008 & 0.0034 & 0.0143 \\
\hline 26 & 0.041 & 0.318 & 0.0086 & - & 0.0179 & - & 0.0034 & 0.0036 \\
\hline 30 & 0.041 & 0.318 & 0.0110 & - & 0.0179 & 0.0004 & 0.0034 & 0.0036 \\
\hline 31 & 0.035 & 0.318 & 0.0086 & - & 0.0269 & 0.0004 & 0.0034 & 0.0068 \\
\hline 38 & 0.032 & 0.156 & 0.0260 & 0.656 & 0.0260 & 0.0010 & 0.0030 & 0.0020 \\
\hline 43 & 0.032 & 0.144 & 0.0190 & 0.420 & - & 0.0010 & 0.0030 & 0.0020 \\
\hline 47 & 0.032 & 0.144 & 0.0210 & 0.388 & 0.0180 & - & 0.0030 & 0.0020 \\
\hline 49 & 0.032 & 0.144 & 0.0260 & 0.587 & 0.0260 & 0.0010 & 0.0060 & 0.0060 \\
\hline 53 & 0.032 & 0.156 & 0.0210 & 0.519 & 0.0180 & - & 0.0060 & 0.0050 \\
\hline 55 & 0.035 & 0.136 & 0.0240 & 0.420 & 0.0260 & - & 0.0060 & 0.0040 \\
\hline 64 & 0.035 & 0.136 & 0.0310 & 0.621 & 0.0610 & 0.0010 & 0.0090 & 0.0070 \\
\hline Rataan (Average) & 0.0360 & 0.2361 & 0.0173 & 0.5159 & 0.0228 & 0.0009 & 0.0043 & 0.0050 \\
\hline $\begin{array}{l}\text { Simpangan baku } \\
\text { Standard deviation }\end{array}$ & 0.0039 & 0.0885 & 0.0073 & 0.1084 & 0.0129 & 0.0004 & 0.0018 & 0.0033 \\
\hline
\end{tabular}

Trichodesmium, Ceratium, Dinophysis, dan Chaetoceros. Indeks keragaman dan indeks dominansi plankton adalah $0,89-1,36$ dan $0,05-0,20$.

Data kualitas air yang mempunyai pengaruh dominan dan relatif tidak mengalami perubahan yang cepat dilakukan interpolasi untuk mengetahui pola spasial dari data tersebut. Gambar 4 menampilkan beberapa data parameter fisik perairan hasil interpolasi. Data yang perubahannya cukup dinamis (contohnya: arus, suhu, salinitas) dibuat hanya untuk mendapatkan gambaran pola sebaran spasial pada saat pengambilan data tersebut. Sehingga dapat membantu dalam menganalisis kelayakan lahan budi daya laut.

\section{Kondisi Sosial Ekonomi}

Kondisi sosial ekonomi merupakan aspek penting dalam rangka pengembangan kegiatan budi daya laut. Kondisi sosial ekonomi masyarakat di sekitar lokasi penelitian dianalisis secara terpisah, karena sifatnya umum untuk seluruh wilayah perairan. Dari hasil wawancara dengan 22 responden yang mewakili dua kecamatan yaitu Kecamatan Manggelewa dan Kempo menunjukkan bahwa kegiatan budi daya ikan dalam KJA dan budi daya mutiara umumnya belum berkembang. Kegiatan budi daya laut yang telah dan banyak berkembang adalah budi daya rumput laut
(Tabel 4). Permasalahan utama yang menyebabkan belum berkembangnya kegiatan budi daya laut menurut Syaiful et al. (2001) adalah terbatasnya kegiatan uji coba paket teknologi, terbatasnya kemampuan petani (modal dan keterampilan), dan terbatasnya persediaan bibit/benih serta belum terbinanya mitra usaha yang baik.

Produksi perikanan yang dihasilkan di sekitar daerah penelitian tidak hanya dipasarkan secara lokal (Kabupaten Dompu), namun juga dipasarkan keluar daerah. Beberapa lokasi yang menjadi target pemasaran meliputi: Bima, Bali, dan Pulau Jawa. Struktur rantai pemasaran hasil perikanan di Kecamatan Manggelewa dan Kempo disajikan pada Gambar 5. Dalam pemasaran hasil perikanan di Kecamatan Manggelewa dan Kempo terdapat tiga saluran pemasaran utama. Pertama adalah nelayan menjual ke padagang pengumpul, dari pedagang pengumpul dijual ke pedagang pengecer, dan dari pedagang pengecer dijual ke konsumen akhir. Kedua adalah nelayan menjual ke pedagang pengumpul, dari pedagang pengumpul dijual ke pedagang pengumpul besar, dari pedagang pengumpul besar dijual ke konsumen akhir di luar daerah. Alur ketiga adalah nelayan menjual langsung ke konsumen akhir dan kadangkala konsumen datang langsung ke nelayan.

Sarana dan prasarana penunjang kegiatan budi daya laut di lokasi penelitian dirasakan telah 


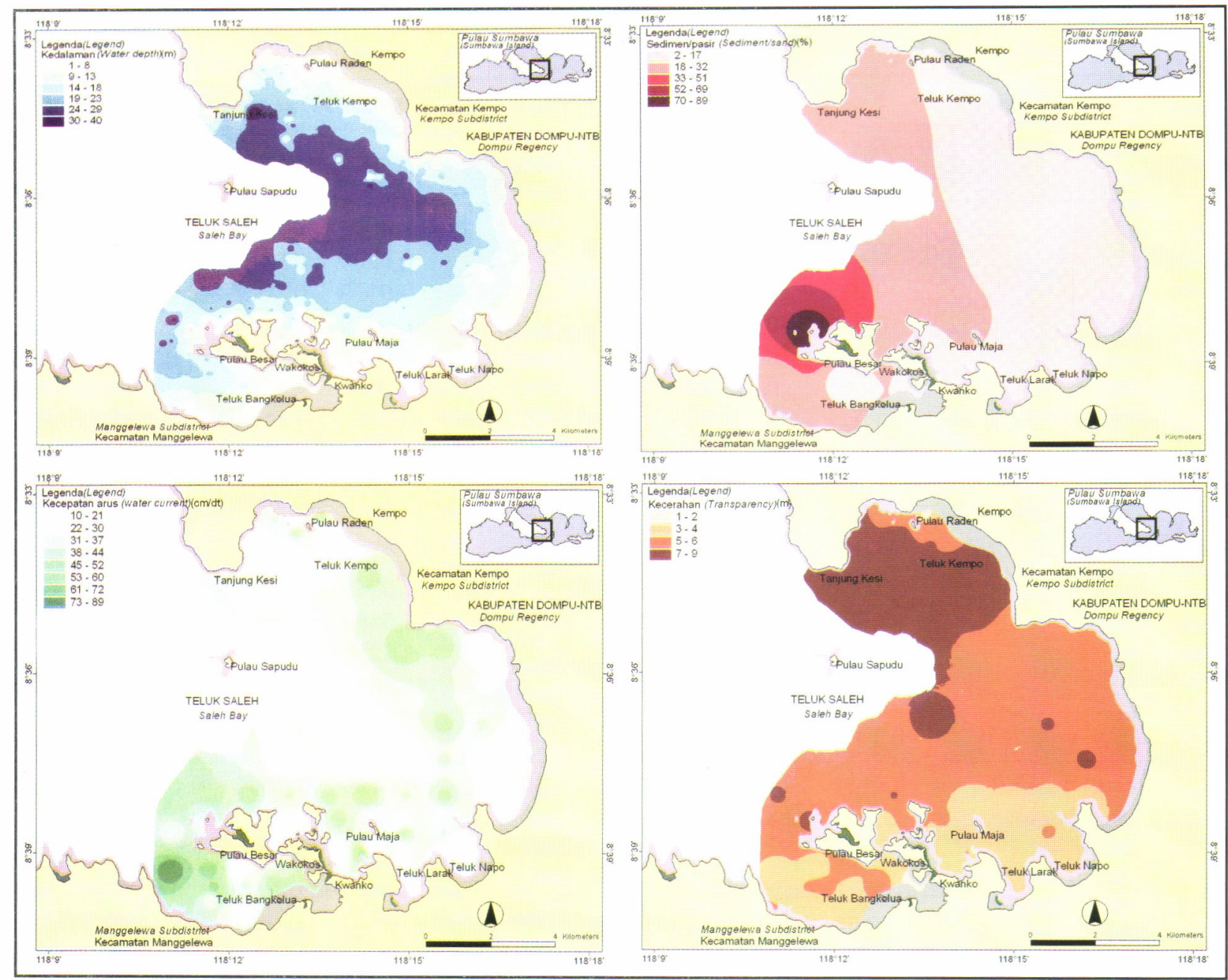

Gambar 4. Sebaran spasial kualitas perairan di Teluk Saleh, Kabupaten Dompu: (a) kedalaman, (b) sedimen/ pasir, (c) kecepatan arus, dan (d) kecerahan

Figure 4. Spatial distribution of water quality at Saleh Bay, Dompu Regency: (a) water depth, (b) sediment/sand, (c) water current, and (d) transparency

mendukung kegiatan usaha. Jalur transportasi menuju lokasi budi daya umumnya sudah tersedia, baik itu jalan aspal maupun batu/tanah yang bisa dilalui oleh kendaraan roda empat. Penerangan juga telah tersedia baik menggunakan genset maupun dari PLN. Dukungan pemerintah daerah juga dirasakan oleh kelompok nelayan pembudi daya berupa pembinaan dari Dinas Kelautan dan Perikanan Kabupaten serta dibuatnya demplot KJA dengan bantuan dana APBN (INBUDKAN). Namun dalam pengembangannya, masalah keamanan dirasakan masih kurang dengan banyaknya terjadi pencurian. Selain itu harga jual

Tabel 4. Jenis kegiatan budi daya laut di lokasi studi

Table 4. Mariculture activities at research location

\begin{tabular}{|c|c|c|}
\hline $\begin{array}{l}\text { Kecamatan } \\
\text { District }\end{array}$ & $\begin{array}{c}\text { Desa } \\
\text { Sub district }\end{array}$ & $\begin{array}{c}\text { Jenis usaha } \\
\text { Mariculture activities }\end{array}$ \\
\hline Manggelewa & $\begin{array}{l}\text { Kwanko } \\
\text { Pulau Secangkir } \\
\text { Secangkir Island } \\
\text { Nang Tumpu }\end{array}$ & $\begin{array}{l}\text { Budi daya rumput laut dan ikan dalam KJA } \\
\text { Sea weed and marine cage culture } \\
\text { Budi daya rumput laut dan ikan dalam KJA } \\
\text { Sea weed and marine cage culture } \\
\text { Budi daya rumput laut (Sea weed culture) }\end{array}$ \\
\hline Kempo & Soro & Budi daya rumput laut (Sea weed culture) \\
\hline
\end{tabular}




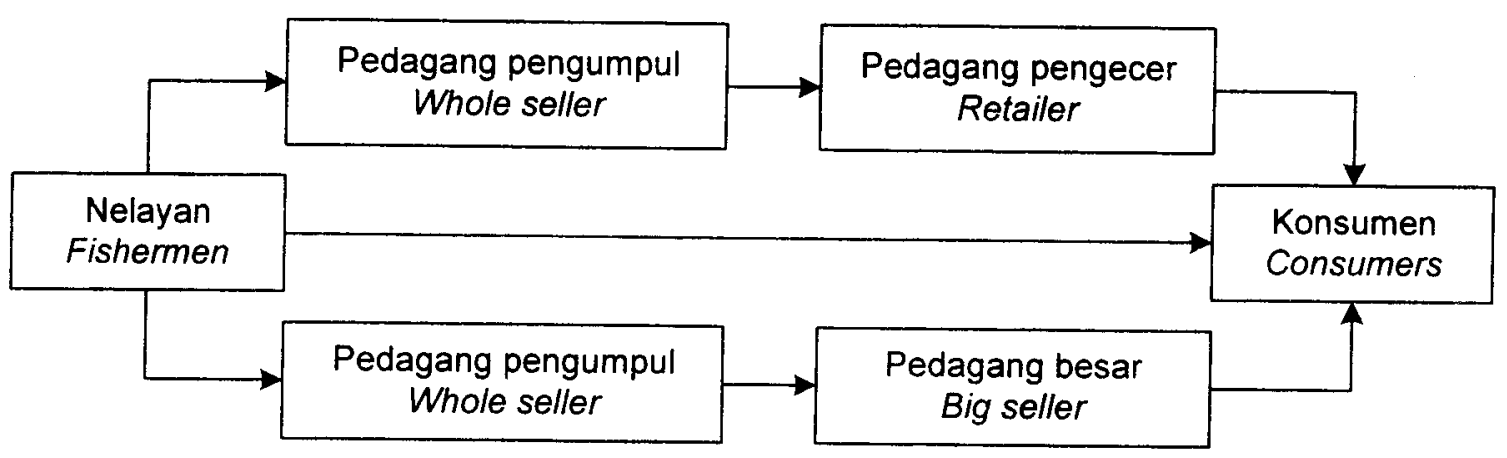

Gambar 5. Saluran pemasaran hasil perikanan di Kecamatan Manggelewa dan Kempo Figure 5. Marketing channel of fisheries product at Manggelewa and Kempo

produk yang masih rendah dan kurangnya biaya (modal) usaha merupakan kendala lain yang belum terpecahkan.

\section{Status Peruntukan Lahan}

Kabupaten Dompu mempunyai potensi lahan budi daya laut sebesar 3.973 ha yang diperuntukkan bagi komoditas rumput laut, mutiara, kekerangan, kakap putih, kerapu, dan teripang. Namun dari potensi yang ada tersebut baru dikembangkan untuk komoditas rumput laut dan mutiara dengan luasan masingmasing 124 ha dan 78,5 ha (Syaiful et al., 2001). Gambar 6 menyajikan sebaran kegiatan budi daya laut yang telah berkembang di sekitar lokasi penelitian.

Potensi lahan budi daya rumput laut yang berada di Kabupaten Dompu terdapat pada enam kecamatan meliputi: Wajo (100 ha), Manggelewa (238 ha), Kempo (250 ha), Pekat (200 ha), Hu'u (139 ha), dan Kilo (371 ha). Dari keenam kecamatan tersebut hanya di Kecamatan Manggelewa (Gambar 6), Kempo, dan Kilo yang baru dapat dimanfaatkan, dengan luasan masingmasing sebesar: 73 ha, 42 ha, dan 9 ha. Jenis rumput laut yang dikembangkan umumnya dari jenis Eucheuma spinosum dan E. cottoni menggunakan metode long line.

Kegiatan budi daya ikan dalam KJA dan budi daya mutiara belum banyak berkembang. Kegiatan budi daya ikan dalam KJA di lokasi penelitian baru ditemukan sebanyak 2 unit yaitu milik Dinas Perikanan dan Kelautan dari program INBUDKAN (Gambar 7) dan milik pengusaha yang pada saat survai dilakukan sedang dalam penyelesaian konstruksi KJA. Komoditas yang dibudidayakan adalah darijenis ikan kerapu. Sedangkan untuk budi daya mutiara baru berkembang di Kecamatan Pekat dan Kilo (Syaiful et al., 2001).

\section{Lokasi Pengembangan Budi Daya Laut}

Dari hasil scoring dan pembobotan data kualitas air serta didukung oleh berbagai pertimbangan sosial ekonomi serta pemanfaatan lahan bagi sektor lainnya, maka terwujud suatu peta tingkat kelayakan lahan bagi kegiatan budi daya laut. Peta tingkat kelayakan lahan yang ditampilkan hanya pada tingkat yang dapat dikembangkan (kategori sangat layak). Lokasi penelitian di Teluk Saleh dengan luasan perairan mencapai 8.012 ha memiliki lahan pengembangan kawasan budi daya yang sangat layak untuk KJA seluas 267 ha atau hanya sebesar $3 \%$ dari total luasan lokasi penelitian, untuk budi daya rumput laut seluas 542 ha atau hanya sebesar $7 \%$ dari total luasan lokasi penelitian, dan untuk budi daya tiram mutiara seluas 163 ha atau hanya sebesar $2 \%$ dari total luasan lokasi penelitian. Peta tematik kelayakan lahan budi daya laut dapat dilihat pada Gambar 8.

Bagi pengembangan usaha yang berkelanjutan, maka potensi yang ada sebaiknya tidak dimanfaatkan seluruhnya, tetapi harus disediakan area yang fungsinya sebagai penyangga. Sehingga nantinya dalam pengembangan budi daya laut efek penurunan kualitas lingkungan dapat diminimalkan.

Untuk budi daya ikan dalam KJA, dengan pertimbangan bahwa 1 ha lahan budi daya dapat dimanfaatkan secara efektif untuk 40 unit KJA (10\% dari luasan ideal), di mana 1 unit keramba terdiri atas 4 keramba dengan ukuran per keramba 2,5 $\times 2,5 \times 3,5$ $\mathrm{m}^{3}$ (Imanto, 2000; Hanafi et al., 2001), maka jumlah keramba yang dapat dioperasionalkan di perairan unit pengembangan kawasan budi daya adalah mencapai 10.680 unit KJA, untuk padat tebar keramba yang optimal dapat mencapai $20 \mathrm{ekor} / \mathrm{m}^{3}$ (Imanto, 2000).

Untuk budi daya rumput laut, 1 ha lahan budi daya dapat dimanfaatkan secara efektif untuk 20 unit usaha menggunakan metode rakit atau long line dengan ukuran 2,5 $55 \mathrm{~m}^{2}$ (Mubarak et al., 1990), maka jumlah rakit yang dapat dioperasionalkan di lahan pengembangan kawasan budi daya adalah mencapai 10.840 unit.

Untuk budi daya tiram mutiara, jika pemanfaatannya hanya $10 \%$ dari lokasi yang layak, 


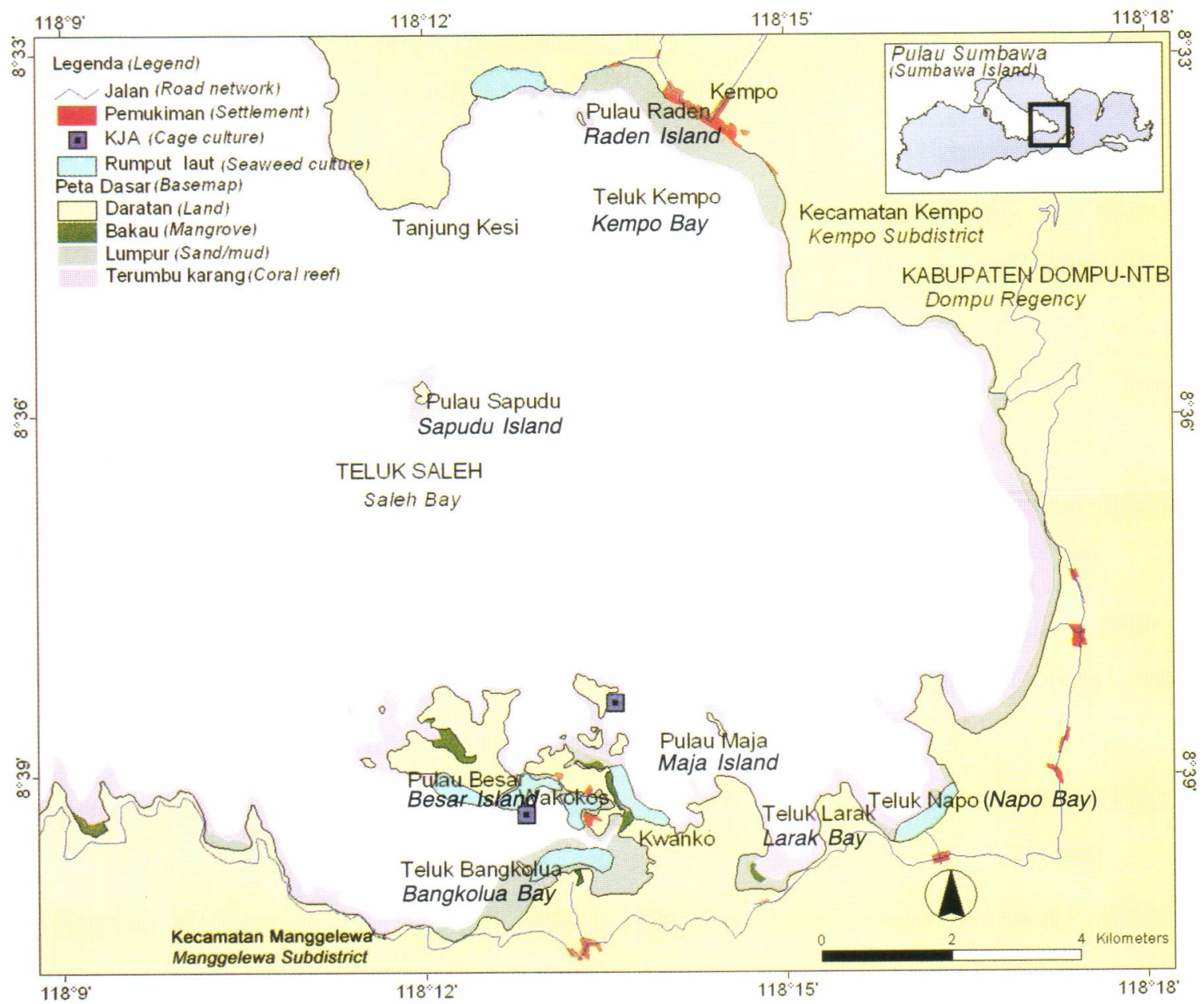

Gambar 6. Peta sebaran budi daya laut yang telah ada di Teluk Saleh

Figure 6. Map of existing mariculture activities at Saleh Bay

A
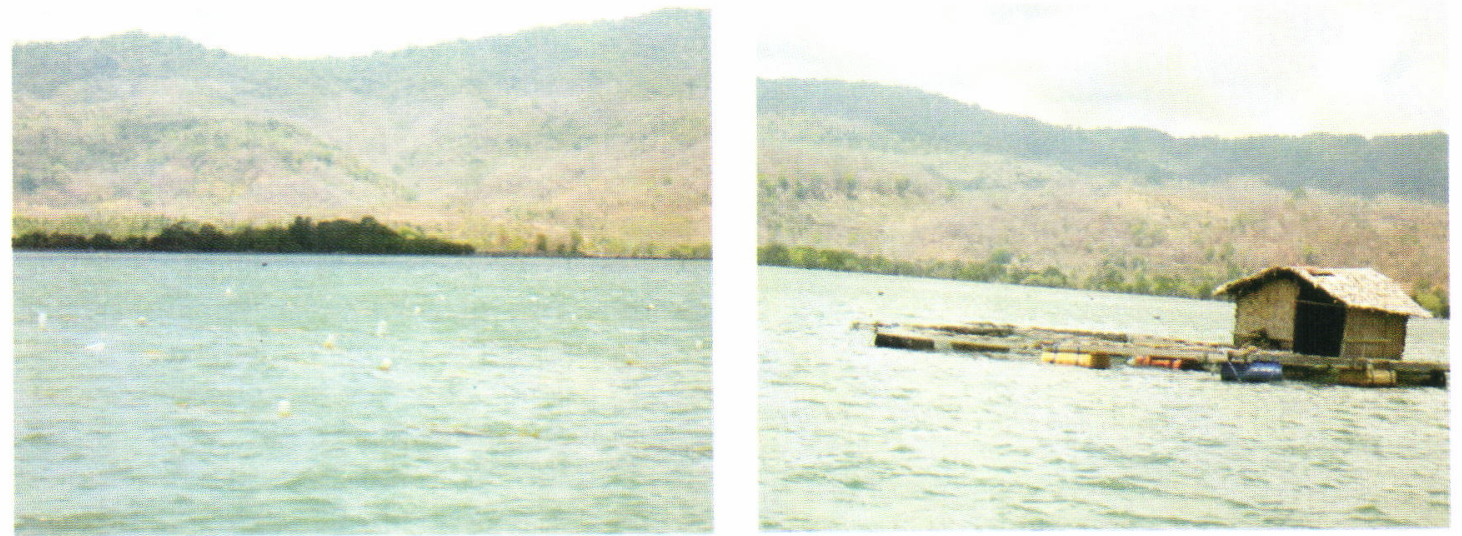

Gambar 7. Kegiatan budi daya laut yang ada di Kecamatan Manggelewa; (a) budi daya rumput laut, (b) budi daya ikan dalam KJA

Figure 7. Existing mariculture activities at Manggelewa; (a) seaweed culture, (b) marine fish cage culture

maka luasan area yang dapat dimanfaatkan adalah seluas 16 ha. Berdasarkan morfologi lokasi maka metode yang dapat dikembangkan adalah metode long line dan rakit (CMFRI, 1991). Metode rakit digunakan pada lokasi yang cukup terlindung sedangkan untuk lokasi yang agak terbuka penggunaan metode long line lebih sesuai. Ukuran rakit/long line yang biasa digunakan adalah $6 \times 5 \mathrm{~m}^{2}$. 


\section{KESIMPULAN DAN SARAN}

Teluk Saleh yang termasuk wilayah pengelolaan dua kabupaten (Kabupaten Sumbawa dan Dompu) dengan karakteristik wilayah perairannya, mempunyai potensi yang cukup besar untuk pengembangan budi daya rumput laut dan ikan (kerapu dan kakap putih), kekerangan (mutiara) dan teripang.

Daya dukung lahan di lokasi penelitian cukup potensial untuk pengembangan budi daya laut karena kondisi kualitas perairan (fisik, kimia, dan logam berat) masih dalam kisaran yang baik, serta adanya dukungan sarana prasarana yang memadai dan keterlibatan pemerintah daerah setempat (Dinas Kelautan dan Perikanan) dalam pengembangannya. Dengan memanfaatkan data inderaja (Landsat ETM+) yang dipadukan dengan data lapangan serta dianalisis dengan SIG menunjukkan bahwa luas daerah penelitian di Teluk Saleh mencapai 8.012 ha memiliki lahan pengembangan kawasan budi daya yang sangat layak untuk KJA seluas 267 ha atau hanya sebesar $3 \%$ dari total luasan lokasi penelitian, untuk budi daya rumput laut seluas 542 ha atau hanya sebesar $7 \%$ dari total luasan lokasi penelitian, dan untuk budi daya kerang mutiara seluas 163 ha atau hanya sebesar $2 \%$ dari total luasan lokasi penelitian.

Sosialisasi area pengembangan harus dilakukan secara menyeluruh dengan melibatkan semua komponen baik pemerintah maupun masyarakat, sehingga konflik pemanfaatan lahan bisa dihindari dan usaha budi daya dapat tetap berlanjut.

\section{UCAPAN TERIMA KASIH}

Pada kesempatan ini penulis mengucapkan terima kasih kepada semua anggota tim, dari Pusat Riset Perikanan Budidaya dan Instalasi Riset Budidaya Ikan Hias Air Tawar, Depok yang telah membantu pelaksanaan riset ini.

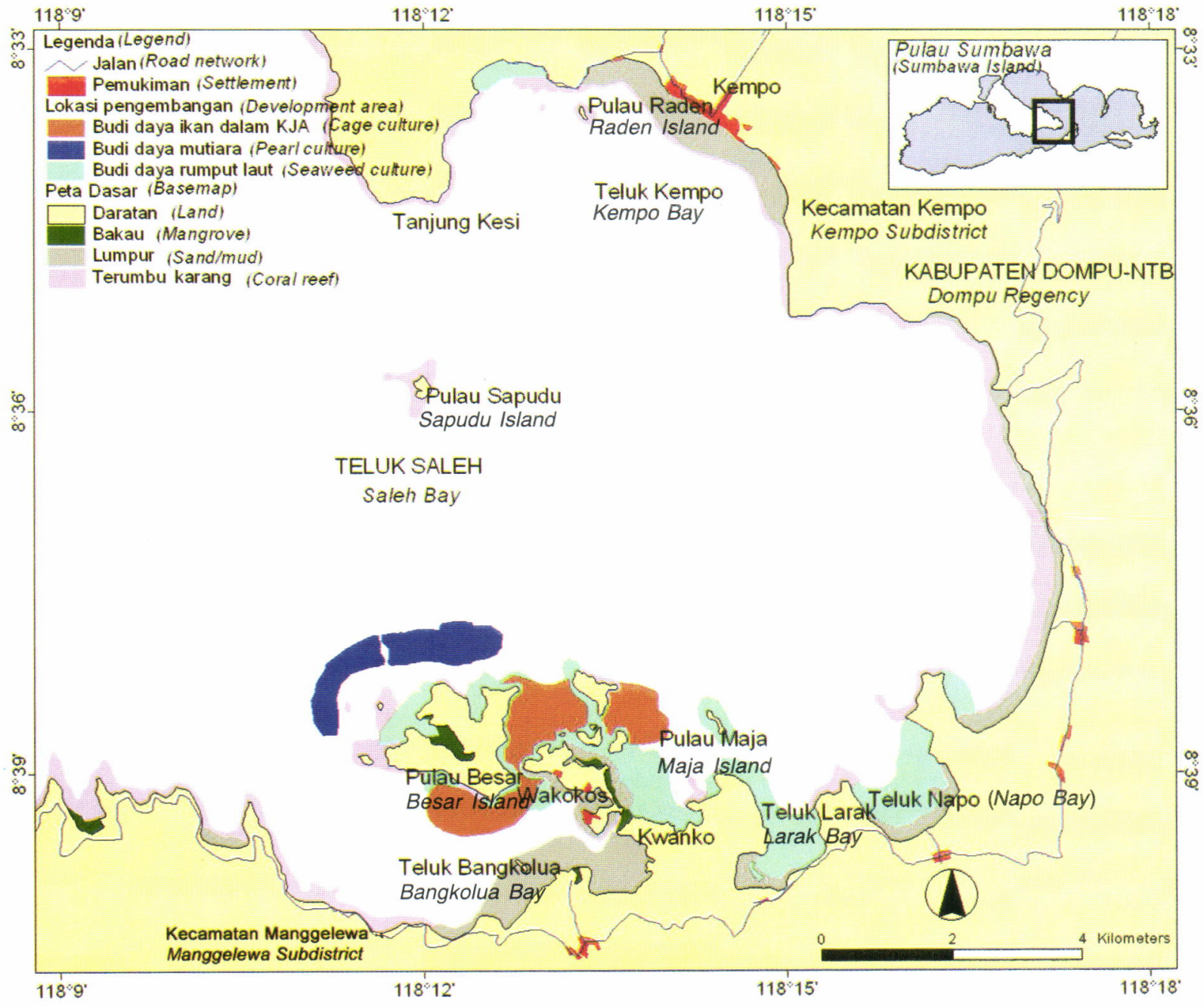

Gambar 8. Peta kelayakan lahan budi daya laut di Teluk Saleh Figure 8. Area suitability map for mariculture at Saleh Bay 


\section{DAFTAR PUSTAKA}

Ahmad, T., A. Rukyani, dan A. Wijono. 1995. Teknik budi daya laut dengan keramba jaring apung. Dalam Sudradjat et al.(eds.). Prosiding Temu Usaha Pemasyarakatan Teknologi Keramba Jaring Apung Bagi Budi Daya Laut. Puslitbang Perikanan, Badan Litbang Pertanian, p. 69--87.

Anonim. 2001. Pokok-Pokok Arahan Tata Ruang Wilayah Pesisir dan Laut Pulau Sumbawa. Propinsi Nusa Tenggara Barat. Badan Perencanaan Pembangunan Daerah-NTB.

APECISEAFDEC. 2001. Pembudidayaan dan Manajemen Kesehatan Ikan Kerapu. APEC, Singapore dan SEAFDEC, lloilo, Philippines, $95 \mathrm{pp}$.

Beveridge, M.C.M. 1996. CageAqua-culture (Eds. $2^{\text {nd }}$ ). Fishing News Books LTD. Farnham, Surrey, England, $352 \mathrm{pp}$.

Burrough, P.A. and R.A. McDonnel. 1998. Principle of Geographical Information Systems. Oxford University Press, $327 \mathrm{pp}$

Central Marine Fisheries Research Institute (CMFRI). 1991. Pearl oyster farming and pearl culture. Training manual on pearl oyster farming and pearl culture in India, FAO Training Manual No. 8. Regional Sea farming Development and Demonstration Project (RAS/90/002). http://www.fao.org/docrep/field/003/ AB726E/AB726E00.htm\#TOC [Juni 2004].

Clark, W.A.V. and P.L. Hosking. 1986. Statistical Methods for Geographers. John Wiley \& Sons, Inc, 513 pp.

Dahuri, R. 2003. Paradigma baru pembangunan Indonesia berbasis kelautan. Orasi Ilmiah: Guru Besar Tetap Bidang Pengelolaan Sumber Daya Pesisir dan Lautan. Fakultas Perikanan dan IImu Kelautan, IPB, $233 \mathrm{pp}$.

Hakim, L., E. Salmah, Sahri, M. Irwan, L. Sukardi, dan Sukardan. 2000. Rencana Strategis Pengelolaan Wilayah Pesisir dan Laut Kabupaten Dompu. Kerja sama Bappeda Kabupaten Dompu dengan Pusat Penelitian Perencanaan Regional Universitas Mataram, $100 \mathrm{pp}$.

Hanafi, A., Tarunamulia, A. Rachman, dan T. Ahmad. 2001. Penataan ruang Teluk Pegametan di Kecamatan Gerokgak, Bali untuk pengembangan sea farming. Dalam Sudradjat et al. (eds.) Teknologi Budi Daya Laut dan Pengembangan Sea Farming di Indonesia. Puslitbang Eksplorasi Laut dan Perikanan, p. 57--69.

Imanto, P.T., N. Listyanto, dan B. Priono. 1995. Desain dan konstruksi keramba jaring apung untuk budi daya ikan laut. Dalam Sudradjat et al. (eds.). Prosiding Temu Usaha Pemasyarakatan Teknologi Keramba
Jaring Apung bagi Budi Daya Laut. Puslitbang Perikanan, Badan Litbang Pertanian, p. 216--230.

Ismail, W., S.E. Wardoyo, dan B. Priono. 1998. Lokasilokasi potensial bagi panti benih terapung ikan karang di Selatan P. Bintan dan Karimun Jawa. J. Pen. Per. Indonesia, IV(1): 36--46.

KLH. 2004. Keputusan Menteri Negara Lingkungan Hidup No. 51 Tahun 2004, Tanggal 8 April 2004 tentang Baku Mutu Air Laut. Kementerian Lingkungan Hidup, Jakarta, $11 \mathrm{pp}$

Morain, S. 1999. GIS Solution in Natural Resource Management: Balancing the Technical-Political Equation. OnWord Press. USA, $361 \mathrm{pp}$

Mayunar, R. Purba, dan P.T. Imanto. 1995. Pemilihan lokasi untuk usaha budi daya ikan laut. Dalam Sudradjat et al. (eds.). Prosiding Temu Usaha Pemasyarakatan Teknologi Keramba Jaring Apung bagi Budi Daya Laut. Puslitbang Perikanan, Badan Litbang Pertanian, p. 179--189.

Mubarak, H., S. llyas, W. Ismail, I.S. Wahyuni, S.H. Hartati, E. Pratiwi, Z. Jangkaru, dan R. Arifuddin. 1990. Petunjuk Teknis Budi Daya Rumput Laut. Pusat Penelitian dan Pengembangan Perikanan, PHP/KAN/ PT/13/1990, Jakarta, 93 pp

Saefudin, S. Budiyono, N. Yustiningsih, I.R. Astuti, dan U. Idawati. 1996. Potensi Pengembangan Perikanan Tambak di Teluk Banten. Pelatihan Sistem Informasi Geografis dan Inderaja Tingkat Perencana. Jakarta, $30 \mathrm{pp}$.

Sukadi, F. 2002. Pengembangan perikanan budi daya untuk mendukung pembangunan nasional. Rapat Kerja Teknis Pusat Riset Perikanan Budidaya, Surabaya 25--26 November 2002, 13 pp.

Supangat, A., T. Wagey, dan S. Burhanuddin. 2003. Daya Dukung Kelautan dan Perikanan Selat Sunda, Teluk Tomini, Teluk Saleh, dan Teluk Ekas. Tim proyek carrying capacity Badan Riset Kelautan dan Perikanan. Departemen Kelautan dan Perikanan, 122 pp.

Sutarmat, T., S. Ismi, A. Hanafi, and S. Kawahara. 2003 Manual for Humpback Grouper Culture (Cromileptes altivelis) in Floating Net Cages. Gondol Research Institute for Mariculture and JICA, $51 \mathrm{pp}$

Syaiful, M., L.M. Azhar, A. Razak, Wahidin, dan Arif. 2001. Penelitian Potensi Pengembangan Kawasan Budi Daya Perikanan dan Kelautan Kabupaten Dompu, kerja sama Bappeda dengan Dinas Perikanan dan Kelautan, $40 \mathrm{pp}$

Treece, G.D. 2000. Site Selection. In Stickney, R.R. Encyclopedia of Aquaculture. John Wiley \& Sons, Inc, p. $869--879$

Winanto, T. 2004. Memproduksi Benih Tiram Mutiara. Penebar Swadaya, Seri Agribisnis, 96 pp. 